\title{
Party Government in Germany and Austria: A New Perspective from the Power Index Approach
}

\author{
Alexander Preker ${ }^{1} \&$ Jan-Erik Lane ${ }^{1}$ \\ ${ }^{1}$ Albert-Ludwigs-University of Freiburg, Germany \\ Correspondence: Alexander Preker \& Jan-Erik Lane, Albert-Ludwigs-University Freiburg, Seminar für \\ Wissenschaftiche Politik, Werthmannstraße 15, 79085 Freiburg, Germany. Tel: 49-761-203-9365. E-mail: \\ alexander.preker@politik.uni-freiburg.de, lane@politik.uni-freiburg.de
}

Received: November 15, 2012 Accepted: December 5, 2012 Available online: January 23, 2013

doi:10.11114/ijsss.v1i1.50

URL: http://dx.doi.org/10.11114/ijsss.v1i1.50

\begin{abstract}
Based on the Banzhaf-Coleman approach to the analysis of political power, this article presents a new analysis of government coalitions. The party systems and types of government formation in Germany and Austria can be compared over time in a new systematic way from 1920. The findings support the theory of democratic stability that emphasizes the power balance between the major right- and left-wing groups in the party system. It can be achieved either by power alternation or through consociationalism.
\end{abstract}

Keywords: party government, coalitions in Germany and Austria, the power index approach, ex ante and ex post power, power imbalance between the left and right wing parties, political stability, Banzhaf numbers.

\section{Introduction}

\subsection{The Context of Coalition Building and Government Formation in Germany and Austria}

In Europe, democracy is practiced through party government under a representative regime, with the possible exception of Switzerland and Liechtenstein, where the referendum institution and the representation principle compete. The politicians under the regime of party government organize in relation to the electorate in the cohesive groups we call "political party". A political party in the advanced capitalist democracies of Europe is characterized internally by a large amount of discipline, and externally by a more or less consistent program and election agenda.

What is the objective of these actors, i.e. the parties in a representative democracy? Reply: The first and foremost goal of any politician is to gain political power (Weber, 1919: 5). But wielding power in government and the legislature is also the key concern for the parties as organized actors, because it is the chief means to other objectives like:

- Party resources: salaries, offices, perquisites;

- Policy-making for its voter groups: taxes, budgets, laws, regulation, etc;

- Participation in government formation processes.

In short: Political parties are always policy-, vote- and office-seeking actors (Strøm, 1984).

Political parties were established in both Germany and Austria in the second half of the $19^{\text {th }}$ century on both sides of the political spectrum, right- and left-wing. Tellingly for the democratic regimes in both countries, however, political parties were introduced under the tumultuous circumstances of the demise of traditional rule. Some of the parties that contested elections in the 1920`s survived the introduction of authoritarianism in the 1930 `s. When understanding national party systems as a result of societal cleavages, this phenomenon can partly be explained by Lipset's and Rokkan's (1967: 50) freezing party system argument, which entails that a party system's build-up reflects the societal structure existing 30 years earlier.

When comparing party government in Germany and Austria before and after the fascist regimes, one can note the great similarity in terms of both political culture and political institutions (cf. Rudzio, 2011/Pelinka, 2004):

- Parliamentarism: Representative government with the focus upon the chancellor; 
- Federalism: Decentralized polity with considerable competences at the centre;

- Election system: PR system employing alternative schemes delivering a high degree of proportionality between votes and seats, generally speaking;

- The decision-making process: A significant committee character and since the after war years also a high degree of (neo)corporatism (Siaroff, 1999).

Also the mass media systems of both countries developed similarly, as their important broadcast stations are mainly based on public law until this day. Focussing these similarities as well as the fact, that both, the German and the Austrian party systems have developed along resembling societal cleavages in the electorate over the last decades (Mielke, 2001; Plasser \& Ulram, 2000; cf. Lipset \& Rokkan, 1967) and as systems of "moderate polarized pluralism" (Sartori, 1976), one has to ask why the logic of party government has tended to be rather different in these two countries - with the political left dominating the Austrian and the political right dominating the German system of government. That is why we compare the two countries' party systems out of a most similar case research design.

\subsection{Power in Nationalrat and Reichstag: On the Importance of the Issue}

Parliament makes a huge number of decisions concerning for instance government formation and support, the budget and taxation as well as regulation in the form of legislation. Additional functions of parliament include controlling government and articulating relevant problems as well as electing government (cf. Rudzio, 2011: 210) under positive parliamentarism (cf. Bergman, 1995). Under party government, the actors in collective decisions are the political parties that tend to vote with one voice, based on their differential number of mandates. Both the constitutional rules of decision-making and the strategy of coalition formation are decisive for the outcomes of parliamentary decision-making.

Most decisions in Parliament require simple majorities, which is why a minimum winning coalition is enough. Sometimes certain decisions of constitutional relevance are singled out requiring a heavier support or qualified majorities. To prevail, a winning coalition would then have to be oversized. In the normal business of government, a simple majority suffices in most parliamentary countries.

A coalition that is minimum winning does not need to be a minimum sized coalition. Actually, coalitions may be of many kinds, but the essential thing is that they win the roll-calls (cf. Riker, 1962). Coalitions may be temporary, focusing upon one voting sequence, or they may be permanent over an election period, such as for instance 4 years. Government coalitions are formed for the purpose of exercising power over a longer period, but government coalitions may break-up prematurely, leading either to a new government or to new elections.

A political party maximizes its voting power by actively participating in the formation of coalitions. If it enters a government coalition, then it shares the voting power of the government with its governing partners. It may also exercise voting power by participating in temporary coalitions that achieve the minimum-winning format. Political power is mainly exercised through the capacity to influence voting in the national assembly. The election system returns the political parties to the German 'Reichstag' or the Austrian 'Nationalrat' roughly according to a numerical size that is decided by the election rules, giving a certain voting support among the electorate. Typical for continental European democracies is the multi-party system, meaning that the parliamentary arena is comprised of three or more political parties, where no party has a majority position.

Classically speaking, political power is defined in terms of relationships, e.g.: „A has power over B to the extent that he can get B to something that B would not otherwise do" (Dahl, 1957: 202 et seq.) Political power under a regime with party government in a multi-party system however derives from the capacity of parties to enter into winning coalitions, either ad hoc in relation to the voting on decision issues in Parliament, or as a permanent coalition government. The Penrose-Banzhaf-Coleman model of coordination in n-person games offers a method to estimate this form of political power, focusing upon coalitions in Reichstag and Nationalrat (cf. Appendix). In short: The Penrose-Coleman-Banzhaf-Model measures also the capacity of a party being successful in contributing to the success of a coalition in representative assemblies.

In this article we wish to show, how the Penrose-Banzhaf-Coleman-method can be employed in a comparative study of party government in Germany, Weimar and FRG, as well as Austria during the $1^{\text {st }}$ and $2^{\text {nd }}$ Republic (1919-1933 and 1945-today). The research question can be posed as such:

Have one or two parties dominated the political game in the national assembly? Or in another phrasing: Have the countries' political parties been able to exercise power in proportion to their electoral support, as measured by the seats of the party in the representative bodies Reichstag and Nationalrat? 
Democratic stability requires that the major political parties are provided with opportunities to wield political parties over time. Thus, when the party system is dominated by the left-right cleavage, then government alternation between the major left and right wing parties is a prerequisite for the stability of the democratic dispensation. One may enquire into this balance between the major political parties by calculating two power index scores: ex ante power measures based upon the election outcomes and ex post power measures based upon the pattern of government formation. The calculation of ex ante power scores is a straightforward solution of the Banzhaf games for parties in the legislature. The calculation of the ex post power scores involves a double Banzhaf game for the parties after government formation, where the parties in a government coalition share whatever power government has, on the basis of a unanimity game.

\subsection{The Parties' Exercise of Political Power: Government Formation and Voting Power - a Theoretical Ap- proximation}

In the 1920s, the Viennese legal scholar Hans Kelsen conducted an intensive debate on the foundations of modern democracy with various scholars, suggesting a variety of critical remarks upon representative government and the position of political parties in the representative assembly. One of the themes, which still resonates, concerned the ambitions of political parties to wield power, affecting public decisions. According to the critiques of democracy, including the German Carl Schmitt, the strength of political parties in parliamentary democracies such as the Weimar Republic led to a contradiction between parliamentarism and democracy. The political parties would target only their own immediate interests in wielding power in the legislature, disregarding national interests. Kelsen replied that modern democracy has to be representative in nature, political parties being a necessary evil (Dreier, 1990: 271-278). There existed no alternative to this principal-agent mechanism, conveying the preferences of the electorate through a party system, although one could hope that the political parties themselves would put break upon excessive fragmentation and opportunism.

The Schmitt-Kelsen controversy raises the highly relevant question of political parties' exercise of power in a representative democracy, for which purposes and how much remuneration they can claim. Under a parliamentary regime, the locus of political power is Parliament. In order to prevail in its decision-making, a political party must be able to form a winning coalition, either by itself or in collaboration with other political parties (Riker, 1962). Many different conzeputalizations have been made to characterize these political parties: the iron law of oligarchy (Michels, 1962), the catch-all party (Kirchheimer, 1965) against the electoral niche party (Lipset \& Rokkan, 1967), the cartel party (Katz \& Mair, 1995) to the principal-agent approach (Lane, 2007). Here, we will thus focus upon power only, more specifically on voting power, different parties may exercise in the national assembly, as the party's access to importance depends upon its parliamentary power, whether the party aims at promoting internal or external objectives (Lane, 2011).

\subsubsection{Party Government and Coalition Theory}

Leaving Schmitt and Kelsen behind, today's most influential approach, which is focussing on the parties' exercise of power, is rational choice based coalition theory. It is always somehow related to game theory, when, for example, conducting transaction costs (cf. Riker, 1962: 183-185). Considering coalition theory, the key to exercising power under parliamentarism with party government lies in the capacity of the political party to enter into winning coalitions, and to be decisive in these coalitions, whether in government or in Parliament. This is still true, when taking later approaches into account, which do emphasize policy-distances, while formulating their extensions to Riker's theory (Axelrod, 1970: 170; De Swaan, 1973: 88). Also Downs' focussing on the parties' office- and especially vote-seeking aims, does back up these assumptions, since also his "economic theory of politics" is based on the premises, that the political process is to win elections in order to gain power (1968: 159). Still, coalition theory, seen as a "a priori approach" (Laver, 1998), is only able to explain coalition making based on the actors' motivations, to join or not to join an ad hoc or stable coalition, which then, for example, could empirically be tested by measuring the ideological distances of competing parties. Therefore, in this article, the Penrose-Banzhaf-Coleman-approach is used as an instrument to explain, why a country has had the coalition-governments it had over time from a perspective, presenting differences in the distribution of power as an explanandum.

\subsubsection{Party Government and the Measurement of Decisiveness}

Facing the parliamentary parties as central actors for government formation, power indices can assess the process of coalition building based on the will of the voter as represented in parliament. Therewith, statements on the importance of parties as central actors in the systems of government can be made. This a priori use of power indices, focussing on coalition building in parliament as a voting body, is quite new. The Penrose-Banzhaf-Coleman-approach originally established as an instrument to estimate differences in the outcomes 
in US national elections, by measuring the voting power of the states in the electoral college (Banzhaf, 1968). Later, power indices were also used to research, if voting power distribution was fair in for example IMF or European Economic Community (Leech, 2002). The Banzhaf numbers in particular were in political science mostly used to proof a country's voting system as fair or unfair in terms of representativeness and decisiveness, by simply counting all possible winning voting coalitions existing, considering that a player's voting behaviour and calculating an index out of it (cf Appendix). Different to another important power index, the Shapley-Shubik-index (1954), the Penrose-Banzhaf-Coleman-approach allows an accurate rating of each player's importance, while the SSI only allows the last player in a game to be pivotal. Further, the Banzhaf index allows several players, here: parties, to be crucial for coalition formation (Holler \& Illing, 2006; cf. Straffin, 1977). An overview over the most relevant literature on this and other differences between the two and other approaches is given in a book edited by Holler and Owen (2001). Still, also there, mathematical (game) theory and the question of translating an actor's votes into voting power for coalition formation are the central discussing points. In this article however, we rather want to look more general on single parties being decisive respectively dominating actors in a party system out of a more applied perspective.

\section{Method: The Penrose-Banzhaf-Coleman Approach}

\subsection{The Banzhaf-Coleman Approach as an Instrument to Explain Coalition Building}

One may distinguish between two parliamentary situations: a majority coalition and a minority coalition. In the first situation the added Banzhaf power scores of government parties adverse parliament equal always 1 . This is a value equally shared by the coalition parties in same proportions, no matter how many seats the party may have won. In the second situation, the government Banzhaf power score is always smaller than 1 . Other parliamentary actors will receive Banzhaf points as well, since the voting power of the government is shared with other parliamentary actors (cf. Lane, 2011).

One may further not only calculate the parties' Banzhaf power indices for both minority and majority coalitions, but also for every legislative period and weighted for every single year. That's what we call modified aggregation. Only by that, the scores can reflect a realistic picture of the existing power structures in a country's parliament and government across time. This especially becomes clear, if looking at the FRG, for example. Firstly Greens and Left Socialists appeared in the party system in the 1980s/90s. Taking their Banzhaf points from 1949 onwards into account would tamper the results. The same objection could be made, when considering, that for example other parties besides CDU/CSU, SPD and FDP competed only in the first years of the early FRG. Furthermore, reunification greatly changed the build-up of the Bundestag (e.g. the number of parliamentarians).

\subsection{The Data and Its Use}

The analysis is made by using the parliamentary shares of seats in the national assemblies of Austria and Germany, compiled by national authorities. The data is covering the periods from 1919-33 in the Weimar republic and from 1949-2012 in the FRG as well as Austria during the $1^{\text {st }}$ republic 1919-1933 and the $2^{\text {nd }}$ republic (1945-today). The nazi-period in both countries is left out of consideration.

Taking this and other specifities of the countries' political systems development into account, the data aggregation is accomplished in two steps. In the first step, the seats and the Banzhaf scores ex ante and ex post government formation are aggregated over time. In a second step, the data is modified by considering only those years, when the parties actually were in parliament or, as the case may be, in power. According to the voting power scores measured by the Banzhaf-Coleman approach, it is then most illuminating to look at the differences between the parties' share of seats in the parliamentary assembly and the share of voting power ex ante and ex post government formation. Especially in contrast to the Shapley and Shubik-approach (1954: 787), which is measuring only one kind of power, ${ }^{1}$ it can hereby be shown, how both the parties' influence- and voting-power can be different from the size they represent in parliament and why some parties dominate the political game, whereas others do not play a big role despite their relative strength (Felsenthal and Machover, 2005: 491). In this paper, this is measured by looking at the deviations from strict proportionality, done by subtrahating the parties' relative share of seats by its Banzhaf points.

\footnotetext{
${ }^{1}$ Felsenthal/Machover (1998) distinguish between „p-power“ (power as a price) und „i-power“ (power as influence). While i-power (as measured by Penrose-Banzhaf-Coleman-approach) also accounts to the policy seeking motives of the parties, $\mathrm{p}$ power (as measured by Shapley and Shubik) only includes the game theoretical „distribution of a fixed purse“, which is the price of power.
} 


\section{Party Government in Germany and Austria}

\subsection{Germany}

\subsubsection{The Weimar Republic}

The average situation of power distribution in the Weimar Republic from 1919-1933 is the following: It was especially the smaller parties and the right wing parties, which often joined government, and which were able to increase their voting- and influence power compared to both their share of seats and their ex ante government status.

When looking at the deviations from strict proportionality, DDP and BVP had larger influence- and voting power compared to their share of seats (DDP +6,7 per cent, BVP +5,3 per cent). Larger conservative parties, which frequently joined government, i.e. Zentrum and DVP, were also expanding their voting power by joining one or more of the mostly minority governments in the Weimar republic. Thereby the (here: external) coalitions can be seen as a latchkey to wield power. They can make minority or majority governments winning. In particular between 1923 and 1929 this was an aim, which was successfully followed by DVP's Gustav Stresemann

Although the Weimar governments often were minority governments, the governing parties had significantly more voting power than they were entitled to, when taking the governmental share of mandates as a basis. This corresponds to the high fragmentation rate of the party system and provides another and new explanation for the appearance of the governments existing during this period and for the dominance of these parties.

Table 1. Banzhaf Power distribution in the Weimar Republic 1919-1933²

\begin{tabular}{|c|c|c|c|}
\hline Party & & $\begin{array}{l}\text { Modified aggre- } \\
\text { gation }\end{array}$ & $\begin{array}{l}\text { Deviations from strict proportional- } \\
\text { ity (power - seats) }\end{array}$ \\
\hline \multirow[t]{3}{*}{ SPD } & seats (rel.) & 0.254736842 & \\
\hline & ex ante & 0.291411 & 0.0366742 \\
\hline & ex post & 0.179639259 & -0.0750976 \\
\hline U SPD & seats (rel.) & 0.154 & \\
\hline \multirow[t]{2}{*}{ (1919-1924) } & ex ante & 0.139715 & -0.014285 \\
\hline & ex post & 0.1057972 & -0.0482028 \\
\hline \multirow[t]{3}{*}{ DNVP } & seats (rel.) & 0.138947368 & \\
\hline & ex ante & 0.126354053 & -0.0125933 \\
\hline & ex post & 0.113363011 & -0.0255843 \\
\hline \multirow[t]{3}{*}{ Zentrum } & seats (rel.) & 0.139635857 & \\
\hline & ex ante & 0.129780053 & -0.0098558 \\
\hline & ex post & 0.155244942 & 0.0156091 \\
\hline \multirow[t]{3}{*}{ BVP } & seats (rel.) & 0.037010234 & \\
\hline & ex ante & 0.034639444 & -0.0023708 \\
\hline & ex post & 0.090371939 & 0.0533617 \\
\hline \multirow[t]{3}{*}{ DVP } & seats (rel.) & 0.084253906 & \\
\hline & ex ante & 0.077607053 & -0.0066469 \\
\hline & ex post & 0.136149469 & 0.0518955 \\
\hline \multirow[t]{3}{*}{ DDP } & seats (rel.) & 0.058270387 & \\
\hline & ex ante & 0.052078947 & -0.00619144 \\
\hline & ex post & 0.124839478 & 0.066569091 \\
\hline NSDAP & seats (rel.) & 0.132896772 & \\
\hline \multirow[t]{2}{*}{ (1924-1933) } & ex ante & 0.148824857 & 0.015928085 \\
\hline & ex post & 0.116784334 & -0.016112438 \\
\hline Wirtschafts- & seats (rel.) & 0.024752883 & \\
\hline \multirow[t]{2}{*}{ partei } & ex ante & 0.023595211 & -0.001157672 \\
\hline & ex post & 0.029837938 & 0.005085055 \\
\hline KPD & seats (rel.) & 0.096936858 & \\
\hline
\end{tabular}

${ }^{2}$ All data contained in this and the other tables represent normalized Banzhaf scores. These were calculated with the help of a computer algorithm for voting power analysis by David Leech. Online:

http://homepages.warwick.ac.uk/ ecaae/\#Progam_List [last review: 26. April 2012]. 


\begin{tabular}{llll}
\hline & ex ante & 0.094663278 & -0.00227358 \\
Dt.-Hannov. & ex post & 0.045465496 & -0.051471362 \\
Partei & seats (rel.) & 0.006994286 & \\
& ex ante & 0.006280333 & -0.000713953 \\
Christl.-nat. & ex post & 0.001587514 & -0.005406772 \\
Landvolk (1924-1933) & seats (rel.) & 0.020770765 & \\
& ex ante & 0.018560071 & -0.002210694 \\
CSVD & ex post & 0.012855946 & -0.007914819 \\
(1930-1933) & seats (rel.) & 0.015807965 & \\
& ex ante & 0.014741333 & -0.001066632 \\
Konservative & ex post & 0.013180917 & -0.002627048 \\
Volkspartei & seats (rel.) & 0.001299827 & \\
$(1930-1932)$ & ex ante & 0.0034224 & 0.002122573 \\
Deutsche & ex post & 0.013798129 & 0.012498302 \\
Bauernpartei & seats (rel.) & 0.010404347 & \\
$(1928-33)$ & ex ante & 0.008974556 & -0.001429791 \\
Others & ex post & 0.003109667 & -0.00729468 \\
& seats (rel.) & 0.006491473 & \\
\hline ex ante & 0.00438 & -0.002111473 \\
\hline ex post & 0.001472844 & -0.005018629 \\
\hline
\end{tabular}

Abbr.: SPD=Sozialdemokratische Partei Deutschlands (social democratic); U SPD=Unabhängige Sozialdemokratische Partei Deutschlands (independent, socialist); DNVP=Deutschnationale Volkspartei (nationalist, conservative); Zentrum=Center party (catholic); BVP=Bayerische Volkspartei (Bavarian, conservative); DVP=Deutsche Volkspartei (liberal); DDP=Deutsche Demokratische Partei (social liberal); NSDAP=Nationalsozialistische Deutsche Arbeiterpartei; Wirtschaftspartei=liberals; KPD=Kommunistische Partei Deutschlands (communists); Deutsch-Hannoversche Partei (local conservative party); Christl.-nat. Landvolk=Christlich-Nationale Bauern- und Landvolkpartei (agrarian, conservative); CSVD=Christlich sozialer Volksdienst (protestant conservative); Konservative Volkspartei=small conservative party; Deutsche Bauernpartei (agrarian).

On the other hand, the social democrats (SPD) or the communist party (KPD) were, for example, after the broad "Weimar coalition" in the national assembly, and in the few years after that, often unable to transform their outstanding mandate strength into effective influence or voting power ex post government formation. Although the social democrats regularly were the largest party in parliament and their ex ante Banzhaf score is greater than their relative mandate strength, they only rarely joined government due to missing coalition options from the mid-1920s on. This is a phenomenon, which is also reflected by the social democratic loss of power from the ex ante to the ex post stage of government formation. Analyzing finally one larger right wing opposition party, the nationalist DNVP, the result is: The DNVP, which often supported one of the (minority) governments, is different in comparison to the governing parties characterized by nearly constantly (high) ex ante and ex post Banzhaf Scores and shows only a small loss of its relative proportion of seats to its power position ex ante government formation.

To sum up: Considering ideology one could state that, based on the presented results, the political centre and the political right is overrepresented both ex ante and ex post government formation, whereas the political left parties, especially the social democrats, are clearly underrepresented in comparison to their relative mandate strength (seats). Therewith it can also be stated, that Hitler's rise to power was also made possible partially 1) by the great fragmentation and 2) by the severe underrepresentation of the political left in terms of government power.

\subsubsection{The Federal Republic of Germany (FRG)}

Looking at the party systems at first glance, the findings for the FRG are very different to those in the Weimar republic. After the first consolidating years with a multi-party system, the German party system was condensed to a 2,5 party system (Poguntke, 1999). From then on, it was characterized by two "catch all" parties (Kirchheimer, 1965) on the one hand, CDU respectively CSU and SPD, and by the FDP as a 0,5 “pivotal” party (Keman, 1994) on the other hand. This setting held for nearly 30 years. However, when looking at the distribution of power, measured by the Penrose-Banzhaf-Coleman-approach, one finding reminds of the Weimar republic: again, the political left is underrepresented in government power. 
Table 2. Banzhaf power distribution in the FRG 1949-2012

\begin{tabular}{llll}
\hline Party & Modified & aggregation & $\begin{array}{l}\text { Deviations from strict proportional- } \\
\text { ity (power - seats) }\end{array}$ \\
\hline CDU/CSU & seats (rel.) & 0.52482205 & \\
& ex ante & 0.501040618 & -0.023781432 \\
ex post & 0.429696945 & -0.095125105 \\
& seats (rel.) & 0.435363492 & -0.134038947 \\
FPD & ex ante & 0.301324545 & -0.180818037 \\
ex post & 0.254545455 & 0.131012158 \\
Grüne (since 1983) & seats (rel.) & 0.111550297 & 0.283601194 \\
& ex ante & 0.242562455 & \\
PDS/ & ex post & 0.395151491 & 0.082957519 \\
Linkspartei.PDS / & seats (rel.) & 0.070312448 & 0.046354219 \\
Die Linke (since 1991) & ex ante & 0.153269967 & \\
Others & ex post & 0.116666667 & 0.016966256 \\
(1949-61) & seats (rel.) & 0.055674471 & -0.055674471 \\
& ex ante & 0.072640727 & \\
\hline ex post & 0.000000000 & 0.00098899 \\
\hline CDU/CSUts (rel.) & 0.01402697 & -0.00101653 \\
\hline
\end{tabular}

Abbr.: CDU/CSU=Christdemokratische Partei Deutschlands/Christlichsoziale Partei Bayerns (Christian democratic); $\mathrm{SPD}=$ Sozialdemokratische Partei Deutschlands (Social democratic); FDP=Freie Demokratische Partei (liberal); Grüne (ecological); PDS=Partei des demokratisches Sozialismus, Linkspartei.PDS, Die Linke (left socialist).

It is remarkable that, in the FRG, typically only the liberal FDP can enlarge its i- and p-power compared to its relative mandate strength. In turn, the Christian democratic CDU, respectively CSU, or "Union" for short, in turn ,is despite small losses, only able to score constantly high Banzhaf points ex ante and ex post government formation. Still, with exception of the Brandt- and Schmidt- and Schröder-years, the FRG was coined as a Christian democratic majority coalition regime with the FDP taking a very powerful position, both due to its pivotal status and its therewith associated status as the longest lasting governmental party. Consequently, the FDP (+28 per cent) and to a smaller amount also the Greens ( $+4,6$ per cent), are the only parties in sixty years of FRG, to receive a positive value ex post government formation, when looking at the deviations from strict proportionality.

These findings are clearly supported, especially by SPD's power scores: again, the social democrats are unable to transform their often distinctive mandate strength into effective influence or voting power in ex post government formation. Although they receive large allocations of seats, they have comparatively little power to win roll-calls. Therefore, their lack of power ex post government formation is also much bigger (-18,1 per cent) than the Christian democratic one (-9,5 per cent).

The weak position of the social democrats in the FRG is valid despite the increased fractionalization of the federal German party system from a 2,5 party system to a polarized four, respectively five, party system during the last two or three decades (cf. Rudzio, 2011). Reason: it is true that these changes also had influence on the distribution of power in parliament, but it was especially the left side of the party system which changed its shape. The SPD has indeed the most coalition options of all relevant parties (Korte \& Fröhlich, 2004), but it also has one of the most different bargaining positions, because of its lack of power. This argument is also supported by the Banzhaf numbers of especially the Greens and Die Linke - at least ex ante government formation, since the latter one is still regarded as "regierungsunfähig" (incapable of governing) by the other four parties. Furthermore, this is a situation, which could in future sharpen and lead to more frequent Grand coalitions, if classifying the uprising Pirate Party as a left one.

\subsection{Austria}

Turning towards Austria, the picture has to be drawn less distinctive: when looking at the first republic, the parties standing politically right were (even heavily) overpowered in comparison to their relative share of seats. On the other hand, in the second republic (1945-today), it is, contrarily, both the Austrian social democrats (SPÖ) and the Christian democratic ÖVP, who are able to enlarge voting- and influence power from the ex ante to the ex post stage of government formation, whereas different to the German system smaller parties (FPÖ, greens or BZÖ) only play a minor role in parliament and government. 


\subsubsection{The First Austrian Republic (1919-1933)}

In the interwar period, after the constitutional assembly in 1918, mainly three political blocks marked the Austrian party system: a socialist (SDAP), a Christian-catholic (Christlichsoziale) and a German nationalist party group, including some smaller parties (Pelinka, 2004: 535). However, as shown by the Banzhaf power distribution ex ante and ex post government formation, it was the Christian social party and the smaller German nationalist party group, which were participating regularly in government, neglected the two grand coalition years from SDAP and Christlichsoziale until the constitution written by Hans Kelsen was established in 1920.

According to this, the SDAP over the years is also heavily underrepresented compared to its relative share of seats $(-25,9$ per cent), whereas the German nationalist party group was extremely overpowered (+31 per cent) in relation to its mandate strength it obtained in the elections.

Although the German nationalist predominance increased over time, both the agrarian Landbund, as well as the paramilitary Heimatbund/Heimwehr formed as secessions from Christlichsoziale and Deutschnationale. However, these new-formed parties could not gain any noteworthy parliamentary power. The German nationalist party group stayed powerful and the Heimwehr especially made its political marks rather outside of parliament a fact, which is reflected by it's both relatively small share of seats and its even smaller Banzhaf power index scores.

Summing up, it can be stated that in the first Austrian republic it was the right wing parties being heavily overpowered once more. This situation can partly also explain the politically smooth change from Austrian parliamentarism to Austrian fascism by Dollfuß in 1933-34 and to the "Anschluss" to Nazi-Germany in 1938 - the SDAP in terms of parliamentary power, literally speaking, was powerless.

Table 3. Banzhaf power distribution in Austria 1919-1933 ( $1^{\text {st }}$ Republic)

\begin{tabular}{llll}
\hline Party & Modified & $\begin{array}{l}\text { Deviations from strict } \\
\text { aggregation }\end{array}$ & $\begin{array}{c}\text { proportionality } \\
\text { (power - seats) modified aggregation }\end{array}$ \\
\hline SDAP & seats (rel.) & 0.326533333 & \\
ex ante & 0.333333333 & 0.0068 \\
Christlichsoziale & ex post & 0.066666673 & -0.259866666 \\
& seats (rel.) & 0.462751467 & \\
ex ante & 0.333333333 & -0.129418134 \\
Deutschnationale & ex post & 0.466666666 & 0.003915199 \\
& seats (rel.) & 0.13902 & \\
Landbund & ex ante & 0.3333333 & 0.1943133 \\
& ex post & 0.449999967 & 0.310979967 \\
Heimatbund/Heimwehr & seats (rel.) & 0.14 & -0.14 \\
& ex ante & 0 & -0.14 \\
ex post & 0 & -0.04424 \\
Others & seats (rel.) & 0.04424 & -0.02646233 \\
& ex ante & 0 & -0.012 \\
& ex post & 0.01777767 & -0.012 \\
\hline
\end{tabular}

Abbr.: SDAP=Sozialdemokratische Arbeiterpartei (social democratic); Christlichsoziale=Christlichsoziale Partei (christian-conservative); Deutschnationle=Deutsch-Nationale Bewegung (nationalist); Landbund (agrarian); Heimatbund/Heimwehr (paramilitary, nationalist).

\subsubsection{The Second Austrian Republic (1945-today)}

When analysing the political system of Germany after 1949, the FRG is often characterized as "The Grand Coalition State" (Schmidt, 1996). This institutional characterization of the political process, based on the politics in the federal system, might also be true for Germany, but when comparing the number of grand coalitions, Austria (10) and not Germany (2) should be named, when asking after "the" grand coalition state. The here computed Banzhaf numbers for the parties ex post government formation in Austria do clearly document this: in general, it is only the two catch all parties increasing their power by forming frequently governments together (SPÖ +42 per cent; ÖVP +27 per cent). When looking at the actual political situation in Austria, these findings appear to be valid, despite the countries' PR-election system and albeit the meanwhile establishment of newer types of coali- 
tion governments or the rise of smaller parties such as the Greens, the Liberals or the nationalist BZÖ. A Grand Coalition again rules Austria since 2007.

Like the German system, the Austrian party system after 1945 was characterized for a long time by a 2,5 party system, existing out of SPÖ, ÖVP and the smaller FPÖ. Different to Germany however, the Austrian FPÖ never reached a "pivotal" status in the party system as the FDP did in Germany. The reason for this political entity, which clearly is shown by a even negative balance from FPÖ's ex post Banzhaf power points vice versa the parties' relative share of seats $(-0,01985507)$, is simple: the party's ability to govern is small due to its right wing and demagogic ideology (Pelinka, 2002: 283).

In contrast to Germany, it is in Austria not the political left, which is underrepresented. In contrast, especially the social democrats can enlarge their parliamentary power by joining government. Due to SPÖ’s slightly higher ex ante Banzhaf score and its therewith slightly better bargaining position in parliament, the second Austrian republic was for a much longer period ruled by social democratic chancellors (nearly 40 years) than the FRG (21 years).

Table 4. Banzhaf power distribution in Austria after 1945 ( $2^{\text {nd }}$ Republic)

\begin{tabular}{|c|c|c|c|}
\hline \multicolumn{2}{|l|}{ Party } & \multirow{2}{*}{$\begin{array}{l}\text { Modified aggregation } \\
0.024675318\end{array}$} & \multirow[t]{2}{*}{$\begin{array}{l}\text { Deviations from strict } \\
\text { proportionality (power - seats) }\end{array}$} \\
\hline KPÖ (1945-1959) & seats (rel.) & & \\
\hline & ex ante & 0.035714293 & 0.011038975 \\
\hline & ex post & 0 & -0.24675318 \\
\hline \multirow[t]{3}{*}{ Greens (since 1986) } & seats (rel.) & 0.074190836 & \\
\hline & ex ante & 0.058608031 & -0.015582805 \\
\hline & ex post & 0 & -0.074190836 \\
\hline \multirow[t]{3}{*}{ SPÖ } & seats (rel.) & 0.433602479 & \\
\hline & ex ante & 0.391257975 & -0.042344504 \\
\hline & ex post & 0.475124378 & 0.041521899 \\
\hline \multirow[t]{3}{*}{ ÖVP } & seats (rel.) & 0.418770529 & \\
\hline & ex ante & 0.366382331 & -0.052388198 \\
\hline & ex post & 0.445273631 & 0.026503102 \\
\hline \multirow[t]{3}{*}{ VdU/FPÖ (since 1949) } & seats (rel.) & 0.104511154 & \\
\hline & ex ante & 0.212018132 & 0.107506978 \\
\hline & ex post & 0.084656084 & -0.01985507 \\
\hline Liberales & & & \\
\hline (1994-99) & seats (rel.) & 0.055737705 & \\
\hline \multirow[t]{2}{*}{$(1994-2002)$} & ex ante & 0 & -0.055737705 \\
\hline & ex post & 0 & -0.055737705 \\
\hline \multirow[t]{3}{*}{ BZÖ (since 2006) } & seats (rel.) & 0.089253188 & \\
\hline & ex ante & 0.142857 & 0.053603812 \\
\hline & ex post & 0 & -0.089253188 \\
\hline
\end{tabular}

Abbr: KPÖ=Kommunistische Partei Österreichs (communistic), Greens= Grünen - Die grüne Alternative (ecological); SPÖ=Sozialdemokratische Partei Österreichs (social democratic); ÖVP=Österreichische Volkspartei (Christian democratic); VdU/FPÖ= Verband der Unabhängigen (1945-55)/since 1955: Freiheitliche Partei Österreichs (right-wing-demagogic, populist); Liberales Forum (liberal); BZÖ=Bündnis Zukunft Österreichs (nationalist-right-wing demagogic, economically liberal).

\section{Conclusion}

The Penrose-Banzhaf-Coleman-approach offers a new game theoretical access to analyze power relations in the parliamentary party systems and to understand the existing parliamentary and governmental power structures in the two countries. Comparing the parties' power scores and especially their deviations from strict mandate-proportionality in Germany and Austria, the strong impact that a small pivotal party in the party systems can have (FDP) as well as which parties have dominated government formation over time become clears.

One can clearly see how the political left in both countries was severely underpowered in the interwar years, which contributed to the fast rise of the fascist regimes, or how, in the after war years, the Christian democratic CDU/CSU and the Liberals (FDP) have dominated German government formation, whereas the social democratic SPÖ has been much stronger in the Austrian system since 1945 than the German Social Democrats by means of consociationalism. These findings have been documented with the Penrose-Banzhaf-Coleman-approach, which tool of cooperative game theory could be used to demonstrate the power relations in the parliamentary systems of other 
countries as well.

\section{References}

Axelrod, R. (1970). Conflict of interest. A Theory of Divergent Goals with applications to Politics. Chicago: Markham Publishing Company.

Banzhaf, J. F. III (1968). One man, ? Votes: Mathematical Analysis of Voting Power and Effective Representation. The George Washington Law Review, 36, 808-823.

Banzhaf, J. F. III (1965). Weighted voting doesn't work: A mathematical analysis. Rutgers Law Review, 19, 317-343.

Bergman, T. (1995). Constitutional Rules and Party Goals in Coalition Formation. An Analysis of Winning Minority Governments in Sweden. Umeå: Umeå University.

Dahl, R. A. (1957). The Concept of Power. Behavioural Science, 2, 201-215. http://dx.doi.org/10.1002/bs.3830020303

De Swaan, A. (1973). Coalition Theories and Cabinet Formations. A study of formal theories of coalition formation applied to nine European parliaments after 1918. Amsterdam: Elsevier.

Downs, A. (1968). Ökonomische Theorie der Demokratie. Tübingen: J.C.B. Mohr (Paul Siebeck).

Dreier, H. (1990). Rechtslehre, Staatssoziologie und Demokratietheorie bei Hans Kelsen (2nd ed.). Baden-Baden: Nomos.

Felsenthal, D. S., \& Machover, M. (2005). Voting power measurement: a story of misreinvention. Social Choice and Welfare, 25, 485-506. http://dx.doi.org/10.1007/s00355-005-0015-9

Felsenthal, D. S., \& Machover, M. (1998). The Measurement of Voting Power. Theory and Practice, Problems and Paradoxes. Cheltenham: Edward Elgar.

Holler, M., \& Illing, G. (2006). Einführung in die Spieltheorie (6th ed.). Berlin/Heidelberg/New York: Springer.

Holler, M., \& Owen, G. (Eds.). (2001). Power indices and coalition formation. Boston/Dordrecht/London: Kluwer Academic Publishers.

Katz, R. S., \& Mair, P. (1995). Changing Models of Party Organization and Party Democracy. The Emergence of the Cartel Party. Party Politics, 1(1), 5-28. http://dx.doi.org/10.1177/1354068895001001001

Keman, H. (1994). The Search for the Centre: Pivot Parties in West European Party Systems. West European Politics, 17(4), 124-148. http://dx.doi.org/10.1080/01402389408425046

Kircheimer, O. (1965). Der Wandel des westdeutschen Parteiensystems. Politische Vierteljahresschrift, 6(1), 12-40.

Korte, K. R., \& Fröhlich, M. (2004). Politik und Regieren in Deutschland. Strukturen, Prozesse, Entscheidungen (2nd ed.). Paderborn et al.: Ferdinand Schöningh.

Lane, J. E. (2011). The Logic of Party Government: A Comparative Perspective. Zeitschrift für Staats- und Europawissenschaften, 9, 522-537.

Lane, J. E. (2007). Comparative Politics: The Principal-Agent Approach. London: Routledge.

Laver, M. (1998). Models of Government Formation. Annual Review of Political Science, 1, 1-25. http://dx.doi.org/10.1146/annurev.polisci.1.1.1

Leech, D. (2002). Computation of power indices. Warwick Economic Research Papers No. 644, The University of Warwick.

Leech, D. (2012). Computer Algorithms for Voting Power Analysis. Online program: http://homepages.warwick.ac.uk/ ecaae/\#Progam_List [last review: 26.April 2012].

Lipset, S., \& Rokkan, S. (1967). Cleavages Structures, Party Systems, and Voter Alignments: An Introduction. In S. Lipset \& S. Rokkan (Eds.), Party Systems and Voter Alignments: Cross-National Perspectives (pp. 1-64). New York: Free Press.

Michels, R. (1962). Political Parties: A Sociological Study of the Oligarchical Tendencies of Modern Democracy. New York/London: Free Press.

Mielke, G. (2001). Gesellschaftliche Konflikte und ihre Repräsentation im deutschen Parteiensystem. Anmerkungen zum Cleavage-Modell von Lipset und Rokkan. In: U. Eith \& G. Mielke (Eds.): Gesellschaftliche Konflikte und Parteiensysteme. Länder- und Regionalstudien (pp. 77-95). Wiesbaden: Westdeutscher Verlag. 
Pelinka, A. (2002). Die FPÖ in der vergleichenden Parteienforschung. Zur typologischen Einordnung der Freiheitlichen Partei Österreichs. ÖZP, 31, 281-290.

Pelinka, A. (2004). Das politische System Österreichs. In W. Ismayr (Ed.), Die politischen Systeme Westeuropas (3rd ed.), Wiesbaden: VS-Verlag, 521-552.

Plasser, F. \& Ulram, P.A. (2000). Parteien ohne Stammwähler? Zerfall der Parteibindungen und Neuausrichtung des österreichischen Wahlverhaltens. In A. Pelinka \& F. Plasser \& W. Meixner (Eds.): Die Zukunft der österreichischen Demokratie. Trends, Prognosen und Szenarien (pp. 169-202). Wien: Signum.

Poguntke, T. (1999). Winner Takes All: The FDP in 1982-1983: Maximizing Votes, Office, and Policy? In W.C. Müller \& K. Strøm (Eds.): Policy, Office or Votes? How Political Parties in Western Europe Make Hard Decisions (pp. 216-236). Cambridge: Cambridge UP.

Riker, W. H. (1962). The Theory of Political Coalitions. New Haven and London: Yale UP.

Rudzio, W. (2011). Das politische System der Bundesrepublik Deutschland (8th ed.). Wiesbaden: VS Verlag. http://dx.doi.org/10.1007/978-3-531-93025-1

Sartori, G. (1976). Parties and Party Systems. A framework for Analysis. Cambridge: Cambridge UP.

Schmidt, M. G. (1996). Germany. The Grand Coalition State. In: J.M. Colomer (Ed.): Political Institutions in Europe (pp. 62-98). London/New York: Routledge.

Siaroff, A. (1999). Corporatism in 24 industrial democracies: Meaning and measurement. European Journal of Political Research, 36, 175-205. http://dx.doi.org/10.1111/1475-6765.00467

Shapley, L. S., \& Shubik, M. (1954). A Method for Evaluating the Distribution of Power in a Committee System. The American Political Science Review, 48, 787-792. http://dx.doi.org/10.2307/1951053

Straffin, P. D. Jr. (1977). Homogeneity, independence, and power indices. Public Choice, 30(1), 107-118. http://dx.doi.org/10.1007/BF01718820

Strøm, K. (1984). Minority Governments in Parliamentary Democracies: The Rationality of Non-Winning Cabi$\begin{array}{lllll}\text { net Solutions. } & \text { Comparative } & \text { Political } & \text { Studies, } & 17,\end{array}$ http://dx.doi.org/10.1177/0010414084017002004

Weber, M. (1919). Politik als Beruf. München/Leipzig: Duncker \& Humblot.

\section{Appendix}

A power index can be an instrument of measuring the ability of each player in a n-player game to contribute to the success of a coalition. The index for each player is defined in terms of the number of times that a player i can influence the coalition by transferring his voting weight. That's what is called a swing $\eta$. The Banzhaf index treats all coalitions as equiprobable. (Banzhaf, 1968: 809) Thus, you can find a total number of $2^{\mathrm{n}}$ coalitions. The non-normalized power index $\beta_{i}$ measures the number of coalitions excluding the player $\mathrm{i}, 2^{\mathrm{n}-1}$, sometimes called absolute voting power. (Leech, 2002) A player's power index $\beta_{i}$ can then be described as follows:

$$
\beta_{i}=\frac{\text { number of swings of a player } i}{\text { total number of coalitions which do not include the player } i}
$$

or in a formula

$$
\beta_{i}=\frac{\eta_{i}}{2^{n-1}}
$$

In order to measure relative voting power $\beta_{i}{ }^{\prime}$ among players the total number of swings for all players is used as the denominator:

$$
\beta_{i}{ }^{\prime}=\frac{\eta_{i}}{\sum \eta_{i}}
$$

\section{(c)) EY}

This work is licensed under a Creative Commons Attribution 3.0 License. 